\title{
Assessing local impacts of the 1700 CE Cascadia earthquake and tsunami using tree-ring growth histories: a case study in South Beach, Oregon, USA
}

\author{
Robert P. Dziak ${ }^{1}$, Bryan A. Black ${ }^{2}$, Yong Wei ${ }^{3}$, and Susan G. Merle ${ }^{4}$ \\ ${ }^{1}$ NOAA/Pacific Marine Environmental Laboratory, Newport, Oregon, 97365, USA \\ ${ }^{2}$ Laboratory of Tree-Ring Research, University of Arizona, Tucson, Arizona, USA \\ ${ }^{3}$ NOAA/Pacific Marine Environmental Laboratory, Seattle, Washington, 98115, USA \\ ${ }^{4}$ Cooperative Institute for Marine Resources Studies, Oregon State University, Newport, Oregon, 97366, USA
}

Correspondence: Robert P. Dziak (robert.p.dziak@noaa.gov)

Received: 5 January 2021 - Discussion started: 27 January 2021

Revised: 27 May 2021 - Accepted: 28 May 2021 - Published: 30 June 2021

\begin{abstract}
We present an investigation of the disturbance history of an old-growth Douglas-fir (Pseudotsuga menziesii) stand in South Beach, Oregon, for possible growth changes due to tsunami inundation caused by the $1700 \mathrm{CE}$ Cascadia Subduction Zone (CSZ) earthquake. A high-resolution model of the 1700 tsunami run-up heights at South Beach, assuming an "L"-sized earthquake, is also presented to better estimate the inundation levels several kilometers inland at the old-growth site. This tsunami model indicates the South Beach fir stand would have been subjected to local inundation depths from 0 to $10 \mathrm{~m}$. Growth chronologies collected from the Douglas-fir stand shows that trees experienced a significant growth reductions in the year 1700 relative to nearby Douglas-fir stands, consistent with the tsunami inundation estimates. The $\pm 1-3$-year timing of the South Beach disturbances are also consistent with disturbances previously observed at a Washington state coastal forest $\sim 220 \mathrm{~km}$ to the north. Moreover, the 1700 South Beach growth reductions were not the largest over the $>321$-year tree chronology at this location, with other disturbances likely caused by climate drivers (e.g., drought or windstorms). Our study represents a first step in using tree growth history to ground truth tsunami inundation models by providing site-specific physical evidence.
\end{abstract}

\section{Introduction}

Recent studies have demonstrated the utility of using treering growth chronologies for assessment of tsunami and earthquake impacts on coastal environments (Buchwal and Szczucinski, 2015; Kubota et al., 2017; Wang et al., 2019). Catastrophic tsunami inundation events along the Sumatran and Japanese coasts have shown tsunamis can have a devastating effect on coastal forests and overall coastal geomorphology (Kathiresan and Rajendran, 2005; Udo et al., 2012; Lopez Caceres et al., 2018). In addition to the physical impacts from tsunamis, Kubota et al. (2017) showed that coastal trees that survived direct physical damage from the great 2011 Japanese tsunami began to die the following summer likely due to the physiological stress of saltwater immersion. Wang et al. (2019) performed a regional assessment of coastal western Washington forests and demonstrated that seawater exposure drives reductions in growth, increased mortality, and greater climate sensitivity regardless of whether the seawater exposure is recent or long-term.

Ground motion caused by the megathrust earthquake can also cause significant forest disturbance by toppling trees, damaging root systems, severing limbs and crowns, inducing damaging landslides, or altering the hydrology of a stand, among other potential effects (e.g., Sheppard and Jacoby, 1989). These disturbances appear in the tree-ring record of surviving trees as sudden growth suppression events (when there is damage) or growth increases in the case of reduced competition from adjacent damaged trees. 


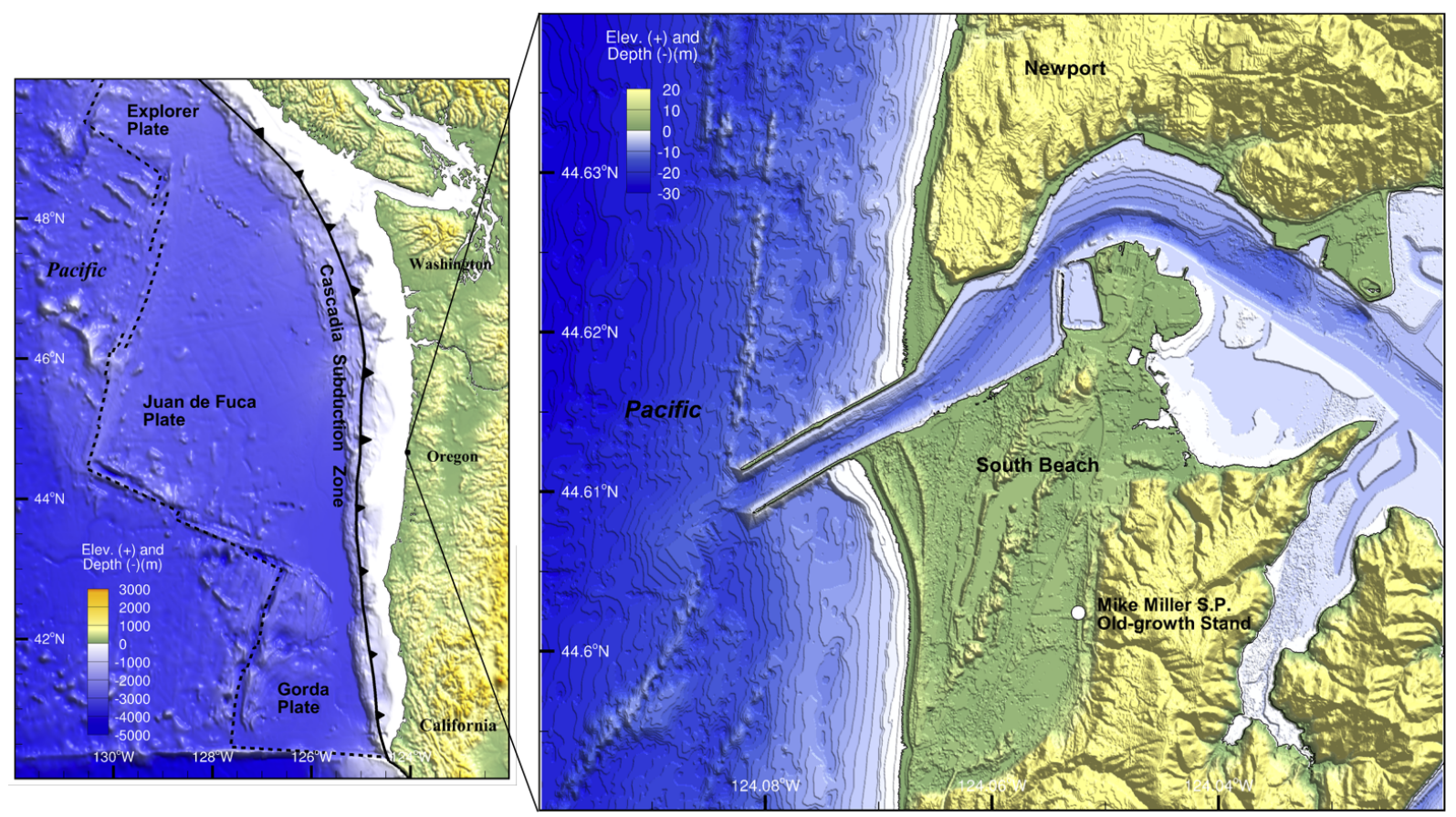

Figure 1. Map showing location of Newport and South Beach along the central Oregon coast. The white dot (at an elevation of $4 \mathrm{~m}$ above mean higher high water, MHHW) shows the position of Mike Miller State Park in South Beach, which is the location of the Douglas-fir tree (Pseudotsuga menziesii) old growth stand whose ages extend back past $1700 \mathrm{CE}$. The state park is located $\sim 2 \mathrm{~km}$ south of the Yaquina Bay, Newport, $\sim 1.2 \mathrm{~km}$ east of the shoreline and $\sim 600 \mathrm{~m}$ east of Highway 101 . Maps were created using digital elevation data points complied by the National Center for Environmental Information (http://ncei.noaa.gov, last access: September 2020) and the State of Oregon's Department of Geology and Mineral Industries (https://www.oregongeology.org/lidar/, last access: September 2020).

Here we present an investigation of the disturbance history of an old-growth forest in South Beach, Oregon (Fig. 1). We also present a new, high-resolution model of the 1700 tsunami run-up heights at South Beach to better estimate the inundation levels at the site of the old-growth forest. Our goal is to use tree growth to ground truth the tsunami impacts and inundation levels, as well as for insights into the degree of shaking caused by the 1700 magnitude 9.0 Cascadia Subduction Zone (CSZ) earthquake (Satake et al., 2003; Witter et al., 2011).

Interestingly, direct evidence of seismic shaking (liquefaction, landslides, etc.) from the $1700 \mathrm{CSZ}$ earthquake is relatively rare along the Oregon Coastal Range (Struble et al., 2020). This is thought to be due to the high rainfall and water erosion rates in the Pacific Northwest which removes liquefaction evidence in coastal estuaries and makes landslides in the coast range difficult to identify (Yeats, 2004; LaHusen et al., 2020). Models of shaking and ground motion along the Oregon coast during the $1700 \mathrm{CSZ}$ earthquake indicate it should have been violent and widespread (WDNR, 2012), and it is plausible that evidence of this shaking might be recorded in the form of traumatic resin ducts and ring width suppression of trees along the coast. Very little tree-ring work has been conducted along the Oregon coast; the vast majority of tree-ring research in the Pacific Northwest has entailed climate reconstructions from high-elevation sites in the Cascade Mountains and Olympic Peninsula where competitive effects are relatively lower. We sampled a mesic old-growth forest near the Pacific coast where competitive effects are high. Significant disturbances from the 1700 earthquake and tsunami should substantially alter radial growth patterns as some trees are damaged or killed and resources are redistributed to survivors. Alternatively, the tsunami may cause physical damage to trees resulting in growth reductions. The goal of this study is to investigate whether these disturbances are observable in the few remaining old-growth forests along the coast of Oregon. Thus, we chose a site where good inundation models exist and where there is significant public concern about tsunami impacts because of the presence of a large population ( $>10000$ people) and municipal infrastructure.

\section{Evidence for megathrust earthquakes and tsunamis}

On 26 January at 21:00 PST (Pacific standard time), $1700 \mathrm{CE}$, a large earthquake occurred along the Cascadia Subduction Zone, the interface between the Pacific and North American plates along the coasts of California, Oregon, Washington, and British Columbia (Satake et al., 2003). The earthquake created a tsunami with $10-12 \mathrm{~m}$ run-up heights 
that struck the Pacific Northwest and propagated across the Pacific to Japan (Atwater, 1992; Satake et al., 2003; Goldfinger et al., 2003). It is estimated to have most likely been a moment magnitude $\left(M_{\mathrm{w}}\right) 9.0$, with between 13 and $21 \mathrm{~m}$ of coseismic slip on an offshore fault $1100 \mathrm{~km}$ long (Satake et al., 2003; Witter et al., 2011). The 1700 earthquake was preceded by an earthquake in $~ 960 \mathrm{CE}$ (740-year interval) and another in $\sim 750 \mathrm{CE}$ (210-year interval), with three additional subduction events before these that make up a recent cluster of six megathrust events over the past 1500 years (Atwater et al., 2003). During the 1700 Cascadia earthquake, ground motion and peak ground acceleration (PGA) are modeled from $\sim 0.5$ to $1.2 \mathrm{~g}$ along the Oregon coast (WDNR, 2012). Thus the shaking during this event would have been violent and widespread.

As a result of subsidence, some coastal forests dropped below sea level and were flooded. Boles and root masses of these trees still remain and can be found from northern Oregon to southern Washington. Radiocarbon dating of this wood showed the earthquake occurred around 1700. However, aligning growth patterns of adjacent living trees with those of the flooded, dead trees consistently showed that the last year of growth was 1699, indicating the earthquake occurred between October 1699 and April 1700 (Yamaguchi et al., 1997). The exact origin time of the earthquake was estimated by calculating the travel time for an unexplained tsunami that struck Japan on 26 January 1700 (Satake et al., 2003; Atwater et al., 2006). Surviving trees also recorded the earthquake's date by anomalous changes in ring width or wood anatomy (Atwater and Yamaguchi, 1991; Jacoby et al., 1997). This tree-ring and dating evidence for coastal disturbance is indeed compelling; however, the evidence was derived from trees along just $100 \mathrm{~km}$ of coastal southern Washington and northern Oregon or $\sim 5 \%$ of the coastline expected to be affected by a Cascadia megathrust earthquake.

Additional methodologies have been employed to assess the coastal-wide impacts of the 1700 earthquake. For example, a coastal-wide inventory of liquefaction features associated with the 1700 earthquake found no features along the Oregon coast despite numerous exposures of clean sand deposits that must be susceptible to liquefaction, even at low levels of seismic shaking (Obermeier and Dickenson, 2000). The locations for these field studies in Oregon were also sites where evidence for great Holocene subduction earthquakes (in the form of crustal subsidence) have been identified (Nelson et al., 1995). The only liquefaction features identified to date (and thus direct evidence of seismic shaking) were found along the Columbia River $35-50 \mathrm{~km}$ east of the coast, and these indicate moderate shaking intensity of $0.2-0.35 \mathrm{~g}$ (Obermeier and Dickenson, 2000).

\section{Model of $1700 \mathrm{CE}$ tsunami}

As a first step in estimating tree disturbance in South Beach, we produced a model of the tsunami inundation level and expected flow speed for the 1700 earthquake based on estimates of size, location, displacement, and coastal subsidence (Fig. 2a-c; Witter et al., 2011). Thus, the modeled run-up height of the 1700 tsunami can be used as a basis to investigate possible impacts along the coast and estuaries of South Beach. Figure $2 \mathrm{a}$ and $\mathrm{b}$ show the model results of tsunami inundation level and flow speed for South Beach assuming the "L"- or large-sized earthquake $\left(M_{\mathrm{w}}=9.0\right)$ for the $1700 \mathrm{CE}$ event (Wei, 2017). The L model assumes a finite-fault source with maximum vertical coseismic displacement of $15.2 \mathrm{~m}$ and subsidence of $\sim 1.03 \mathrm{~m}$ at South Beach (Fig. 2c; Witter et al., 2011). The Witter et al. (2011) coseismic subsidence estimate differs slightly from the Satake et al. (2003) estimate of nearly $1 \mathrm{~m}$ at South Beach because it is based on coseismic slip from turbidite records (Goldfinger, 2011) and includes a rupture model with slip partition into a splay fault in the accretionary wedge. The earthquake source duration was not taken into account in the model.

Two models were used to compute the tsunami inundation levels and flow speed (Wei, 2017) based on fourlevel one-way nested model grids at the spatial resolutions of $1 \operatorname{arcmin}(\sim 1.8 \mathrm{~km}), 12 \operatorname{arcsec}(\sim 360 \mathrm{~m}), 2 \operatorname{arcsec}$ $(\sim 60 \mathrm{~m})$, and $1 / 6 \operatorname{arcsec}(\sim 5 \mathrm{~m})$. The tsunami simulation model MOST (Method of Splitting Tsunami) (Titov and Gonzalez, 1997) used in this study is based on the shallowwater wave equations and uses the estimates of coseismic slip to account for deep-water wave generation and propagation. The present MOST code version utilizes the graphics processing unit (GPU) technology that has led to significant reduction of computational time. The MOST model then provides the boundary conditions computed from the level1 grid (Fig. 2a) for a Boussinesq model (Zhou et al., 2011), which takes into account wave dispersion when computing the nearshore wave-propagation field and onshore tsunami inundation in level-2, level-3, and level-4 grids (Fig. 2b shows the coverage of level-4 grid). The digital elevation model (DEM) and bathymetric grid of Newport and South Beach in level 4 were used in the tsunami inundation models. The elevation grid is derived from the digital elevation model provided by the Oregon Department of Geology and Mineral Industries (DOGAMI). This dataset contains lidar data based on DOGAMI lidar data quadrangles for Toledo south, Newport north, and Newport south. The horizontal datum of the DEM is WGS 84. The vertical datum is NAVD 1988, and it is then converted to mean higher high water (MHHW) level, which is the vertical datum in our tsunami inundation models. MHHW is $2.317 \mathrm{~m}$ above the NAVD 1988 and $1.185 \mathrm{~m}$ above the actual mean sea level (MSL) at Newport according to the datum information at the National Ocean Service (NOS) tide gauge at South Beach. Typically, when performing hazard assessments, mean high water (MHW) 

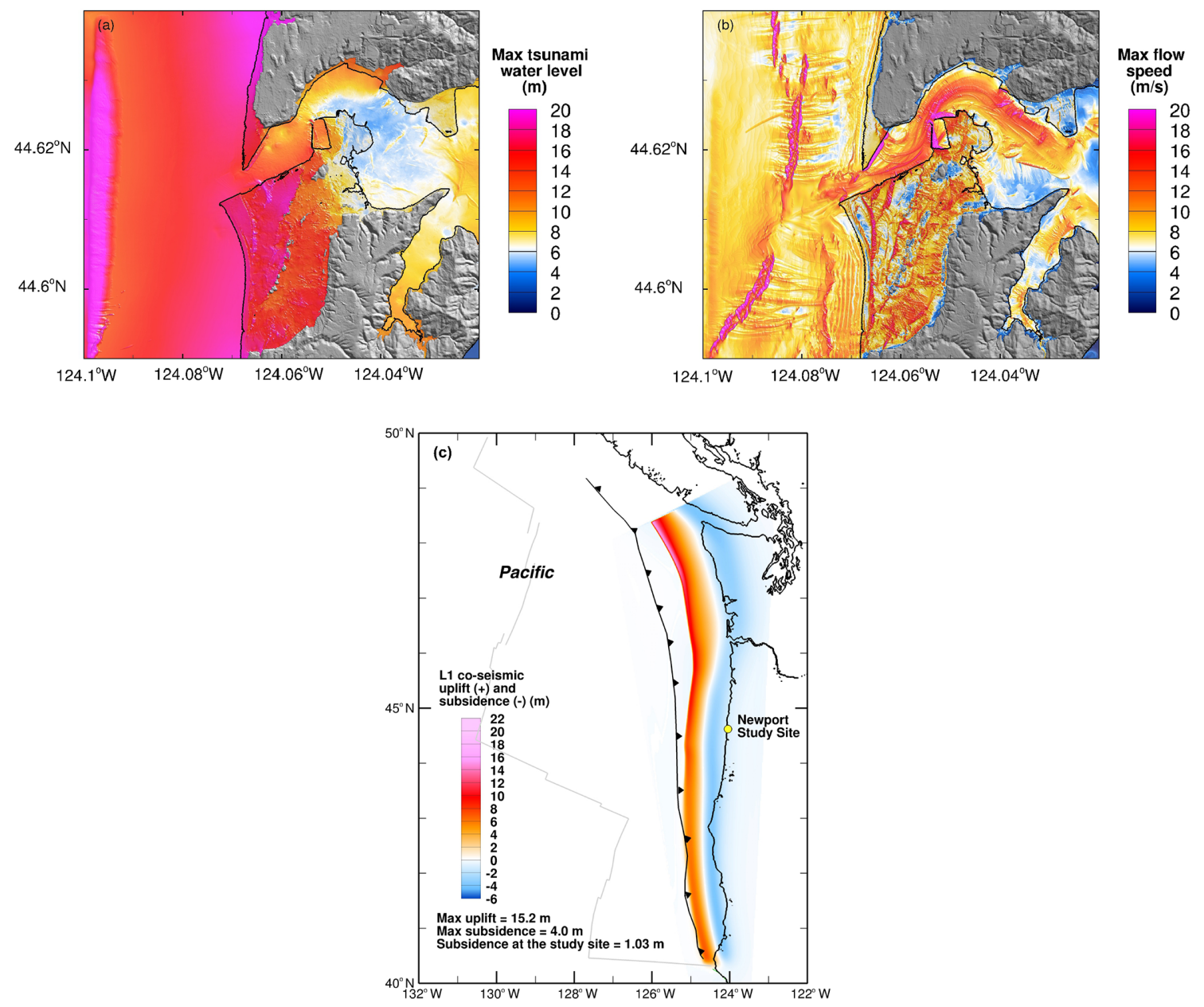

Figure 2. (a, b) Model of the maximum tsunami inundation level and the maximum flow speed for South Beach assuming the L- or largesized earthquake $\left(M_{\mathrm{W}}=9.0\right)$ for the $1700 \mathrm{CE}$ event (Wei, 2017). The L model assumes a finite-area fault source with maximum coseismic displacement of $15.2 \mathrm{~m}$ and subsidence of $\sim 1.03 \mathrm{~m}$ at South Beach. Contour levels are shown. (c) The L model assumes a finite-area fault source with maximum coseismic displacement of $15.2 \mathrm{~m}$ and subsidence of $\sim 1.03 \mathrm{~m}$ at South Beach (Witter et al., 2011).

or MHHW is assumed over the entire duration of a tsunami (Wei, 2017), and using MHHW as the vertical datum usually gives a more conservative estimate of the tsunami impact. In the present study, we prefer to use MHHW, instead of the actual tidal level, as our model reference level due to (1) the uncertainty of the time of the event, which is based on estimates from Japanese records (Satake et al., 1996) and could vary over a window of $1-2 h$; (2) the uncertainty of the earthquake and tsunami source; and (3) the uncertainty in the amount of sea level change, which is $>0.5 \mathrm{~m}$ over the past 300 years based on a rate of $1.77 \mathrm{~mm}$ annual increase. The impact of these uncertainties on the model could overshadow the difference between MHHW and the actual tidal level, and it adds an additional level of uncertainty to the model results. A Manning's coefficient of friction of 0.03 is uniformly applied for both the land and ocean components of the tsunami propagation model. It is an average Manning's coefficient that Chow (1959) proposed for coastal and riverine areas (0.025-
0.033 ) and for land surface (0.03-0.04). It is worth nothing that this Manning's coefficient has been widely used in MOST-based tsunami model forecast methodology and hazard assessments (Tang et al., 2009; Wei et al., 2008, 2013; Titov et al., 2016; Zhou et al., 2011). To more realistically estimate the tsunami impact produced by the 1700 event, we removed the two jetties at the entrance of Yaquina Bay from the model DEMs, which leads to greater tsunami inundation levels and impact at South Beach. The tsunami model results discussed hereafter are based on the revised DEMs without the jetties.

The tsunami inundation model presented here indicates that the L earthquake, with the coseismic subsidence taken into account, would produce a tsunami that could inundate South Beach to run-up heights up to $17 \mathrm{~m}$ (Fig. 2a) and inundation depths up to $16 \mathrm{~m}$ (Fig. 3a and b). The height of the water level at the western section of Mike Miller Park is generally between 12 and $15 \mathrm{~m}$ and reduces to between 9 and 
(a)

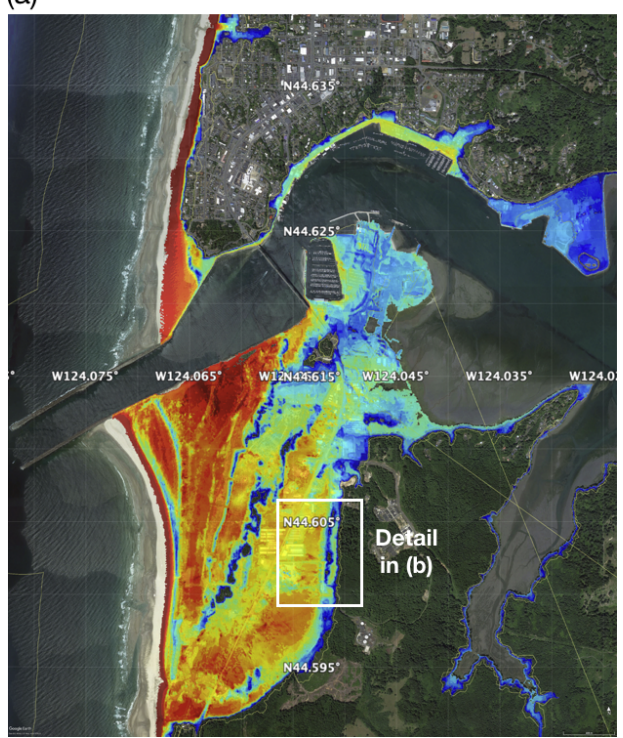

(b)

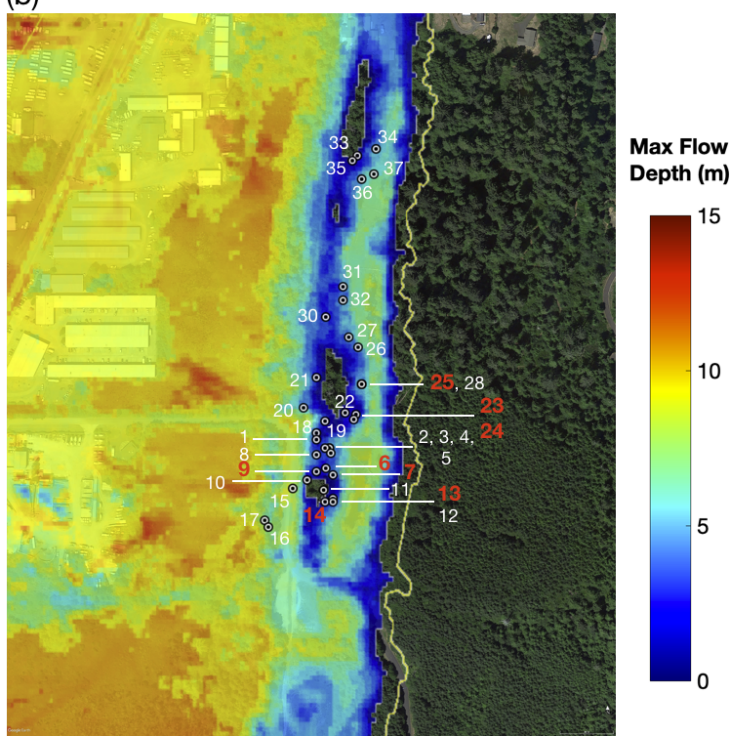

Figure 3. (a) Model of maximum tsunami inundation depth at South Beach for the L-sized earthquake $1700 \mathrm{CE}$ event; (b) zoom-in view of the tsunami inundation depth at Mike Miller State Park. Gray dotted circles show location of trees used in this study on the north side of the stand. Red numbers are the tree locations whose growth chronologies are shown in Fig. 4a and b. White numbers shows trees that were cored, but chronologies do not include the years before $1700 \mathrm{CE}$. Colors on map show inundation depth from the model, implying 0-10 m of inundation depth at the Mike Miller Park Douglas-fir stand. Green areas are high ground locations that show no inundation. The yellow line shows, for comparison, the model of maximum run-up height for the $M_{\mathrm{W}}=9.2$ "XXLarge" earthquake scenario (Priest et al., 2013). Base maps made using (C) Google Earth 2016.

$12 \mathrm{~m}$ on the eastern side. It is important to note that "tsunami water level" is a term used to describe the elevation reached by seawater measured relative to a stated datum (MHHW herein). In contrast, "inundation depth" refers to the local water depth or height of the tsunami above the ground after taking into account the coseismic subsidence at a specific location, as shown in Fig. 2c. However, there is significant variation in the topography of South Beach, and several areas are predicted to experience a range of inundation depths much less than the $16 \mathrm{~m}$ maximum. For example, the model shows the amount of inundation decreases eastward of the beach, and the location of the old-growth Douglas-fir stand at Mike Miller State Park in South Beach may be subjected to a range of inundation depth from negligible to as much as $10 \mathrm{~m}$ (Fig. 3b). Moreover, the South Beach stand would likely have been subjected to flow velocities between 2 and $10 \mathrm{~m} \mathrm{~s}^{-1}$ (Fig. 2b). These velocities are lower than most of the westward portions of the South Beach Peninsula because the stand is located on topography that can have up to $10 \mathrm{~m}$ higher elevation than most of the westward terrain. Nevertheless, it would seem these tsunami current velocities would be high enough to cause significant damage to the South Beach trees through the large mass and momentum of this volume of seawater that would be observable in the tree growth.

Lastly, it is worth noting that the L earthquake tsunami model presented here also involves the activation of splay faults in the overriding plate above the subduction zone. Mo- tion on these splay faults introduce a larger coseismic subsidence along the coastline and therefore represent a more extreme inundation scenario for the $1700 \mathrm{CE}$ event than previous models. Based on the turbidite records reported by Goldfinger et al. (2011), the L and larger earthquake scenarios occurred four times in the past 10000 years and thus are referred to as a 2500-year event, although the general earthquake size class and associated time interval for an $\mathrm{L}$ event is estimated to be 800 years by Witter et al. (2011).

\section{Impacts of earthquakes and tsunami inundation on tree growth}

\subsection{Earthquake-induced ring growth disturbance}

Although there is evidence for only moderate levels of ground shaking in coastal Oregon and Washington following the 1700 earthquake (Obermeier and Dickenson, 2000), ground motion during large earthquakes has been shown to cause significant forest disturbance in other earthquakeprone regions. As previously mentioned, these earthquakeinduced disturbances are caused by felling or damaging trees, inducing local landslides, or altering the stand's water access (Jacoby et al., 1997). Trees that survive these disturbances can show sudden growth suppression events due to damage or even sudden growth acceleration events because of reduced competition from nearby damaged trees. Moreover, 
pulses in tree recruitment may follow a large earthquake as young trees colonize gaps left by damaged overstory individuals (Jacoby et al., 1997).

Trees can respond both directly and indirectly to the effects of large earthquakes. Indirect responses can occur due to coseismic environmental changes. For example, Fuller (1912) noted trees died from flooding during the 1811-1812 New Madrid earthquakes. Wallace and LaMarche (1979) found that coast redwoods (Sequoia sempervirens) and Douglas-firs (Pseudotsuga menziesii) tilted by the 1906 San Andreas Fault earthquake had reaction wood, formed to right the tree, starting in 1907. Meisling and Sieh (1980) reported the January 1857 Fort Tejon earthquake caused conifers to lose their crowns, which reduced ring widths that took many years to return to pre-earthquake growth rates. Jacoby and Ulan (1983) showed the September 1899 Alaskan earthquake caused nearshore Sitka spruces (Picea sitchensis) to increase growth because coseismic uplift resulted in less exposure to wind, salt spray, and rootzone erosion. Finally, in consideration of direct responses to earthquake impacts, Jacoby et al. (1988) analyzed conifer tree-ring samples near the epicenter of the 1812 San Juan Capistrano earthquake. A total of nine on-fault trees showed drastic growth reductions in 1813 , requiring decades to return to pre-disturbance growth rates. Similarly, Sheppard and Jacoby (1989) showed that the 1964 Alaskan earthquake, which caused $\sim 4 \mathrm{~m}$ of coseismic uplift, initially induced growth reduction in Sitka spruces, but the trees eventually responded with wide reaction wood rings in the following years to regain upright positions. Van Arsdale et al. (1998) showed the New Madrid earthquakes of 1811-1812 caused inundation of bald cypress trees near Reelfoot Lake (Tennessee) which greatly increased radial growth from 1812 to 1819 . In contrast, the growth of bald cypress trees in northeastern Arkansas was severely suppressed for almost 50 years following the earthquakes. Wells and Yetton (2004) studied the 1929 Buller and 1968 Inangahua earthquakes in New Zealand, finding clear impacts on tree growth, where swamps on elevated terraces are generally best for preserving earthquake records because they are not affected by drought or wind. As for tree growth disturbances due to earthquake shaking, Fu et al. (2020) showed how the 1950 Zayu-Medog magnitude 8.6 earthquake in the southeastern Tibetan Plateau influenced tree growth during the period 1950-1955. However, alpine trees were less disturbed than those located at middle and low elevations. Severe growth suppressions occurred during the first 3 years after the earthquake and were stronger at low elevations.

\subsection{Tsunami-induced tree-ring growth disturbance}

Just as trees located near epicenters of large earthquakes can be disturbed and experience growth changes from intense shaking and ground displacement, inundation of a coastal forest by a large tsunami should also have a significant impact. Catastrophic tsunami inundation events along the Sumatran and Japanese coasts showed tsunamis have a devastating effect on coastal forests, damaging trees and severely eroding and altering the beach and estuary geomorphology (e.g., Kathiresan and Rajendran, 2005; Udo et al., 2012; Lopez Caceres et al., 2018). It is expected that inundation by a tsunami would cause significant ring-growth reduction due to physical impact from the wave, prolonged exposure to saltwater, and from tsunami debris that would also physically impact the tree. There are several studies demonstrating the impact of the inundation of large amounts of seawater and salts on coastal trees after a tsunami (e.g., Kubota et al., 2017; Wang et al., 2019). These studies showed trees that survived direct physical damage from the tsunami began to die the following summer likely due to the physiological stress of saltwater immersion. Earlywood that formed in the spring following the tsunami had higher $\delta^{13} \mathrm{C}$ values in the rings formed prior to the disaster. In a field survey following the 2010 Chilean and 2011 Japanese tsunamis, Kubota et al. (2017) found that the soil deposits collected in the tsunami-inundated areas are rich in water-soluble ions compared with the samples collected in the non-inundated areas.

In the US Pacific Northwest, when the 1700 CE coseismic tree-ring growth disturbance is considered, it is largely of trees killed by inundation attributed to coseismic subsidence (e.g., Atwater and Yamaguchi, 1991). However, Jacoby et al. (1997) were able to find trees that pre-dated the 1700 Cascadia earthquake and survived subsidence and inundation, which is analogous to the tree-ring growth scenario we observed in South Beach, Oregon.

Jacoby et al. (1997) collected cores from 33 living Sitka spruce trees that were established earlier than 1700 (i.e., at least 300 years old) that stand along the western Columbia River between Washington and Oregon $(\sim 220 \mathrm{~km}$ north of South Beach). While 15 of these trees show some evidence of disturbance at 1700, 5 trees showed no disturbance, and the remaining 14 could be in either category. There were both unusual decreases and increases in ring width in disturbed trees. Disturbed trees also showed waterlogging and increasing numbers of traumatic resin canals at 1700 (sap-conducting tubes formed by altered cells), but only two formed reaction wood in response to coseismic tilting or flooding. Growth responses occurred over a range of years with clear declines occurring as early as 1698 and as late as 1702 to 1706 .

Thus, the exact timing of tree-ring disturbances due to an earthquake and the resulting ground motion, coastal land subsidence, and tsunami inundation can vary within a few years around the event date. This is because tree growth can be affected by many climatological or meteorological factors, including droughts, cold/heat stress, fires, windstorms, and even insect infestations. However, comparison of coastal growth rings with other regional sites can be used to control for these climate and/or weather disturbance impacts. Thus, despite this temporal variability, Jacoby et al. (1997) conclude that the subduction earthquake and subsidence event 
occurred between the growing seasons of 1699 and 1700 . Therefore it seems likely a combination of the effects from earthquake ground motion, coastal land subsidence, and rapid inundation by several meters of fast-moving seawater can be observed in the variation of ring growth chronologies from trees within the impact zone.

\section{Tree-ring growth chronologies from South Beach, Oregon}

In an attempt to further quantify the widespread effects of the $1700 \mathrm{CE}$ earthquake, we obtained tree-ring records from a stand of old-growth Douglas-fir trees (Pseudotsuga menziesii) that pre-date 1700 (Fig. 4a and b). The stand is located in an Oregon State Park in South Beach, Oregon, roughly 600 m east of Highway 101 (Fig. 3a and b). Old growth trees of $300+$ years of age are rare along the Oregon coast; thus this stand of trees within the inundation zone presented a unique opportunity to search for direct physical evidence of the impact of a Cascadia Subduction Zone earthquake and tsunami inundation in a populated area where tsunami models indicate significant inundation levels and run-up heights.

To ground truth the model of the $1700 \mathrm{CE}$ tsunami, we collected tree cores at breast height from 37 dominant or codominant old-growth trees at the South Beach site using a $0.8 \mathrm{~m}$ increment borer. One to two cores were collected from each tree, after which cores were mounted, sanded with increasingly fine lapping film, and cross-dated (Phipps, 1985). Each core was then measured using a Velmex TA tree-ring measuring device to the nearest $0.001 \mathrm{~mm}$ (Velmex, Inc. Bloomfield, NY). Cross dating was then statistically verified using the program COFECHA, which is designed to find errors in chronologies (Holmes, 1983). A master growth-increment chronology was then developed by detrending each measurement time series using negative exponential or regression functions to retain as much low-frequency variability as possible, as well as a second chronology developed using a 50-year $50 \%$ frequency-cutoff cubic spline to highlight interdecadal to interannual growth variability. All chronology construction was performed using the program ARSTAN, a tree-ring standardization program based on detrending and autoregressive time series modeling (Cook and Krusic, 2005). Figure $3 \mathrm{a}$ and $\mathrm{b}$ show the location of the Douglasfir trees sampled for this study in relation to the modeled tsunami run-up heights for South Beach. Of all the trees sampled, a total of 12 cores from 8 trees pre-dated 1700 (Fig. 4b).

As noted, the tsunami inundation model presented here (Fig. 2a and b) indicates the $\mathrm{L}$ earthquake would produce a tsunami that could inundate the lowlands of South Beach to inundation depths up to $18 \mathrm{~m}$. However, the Douglas-fir oldgrowth stand that is the subject of this study lies on and along the western edge of two parallel north-south striking topographic highs (likely paleo-dune ridge lines). The tsunami model presented here indicates that while many of the trees
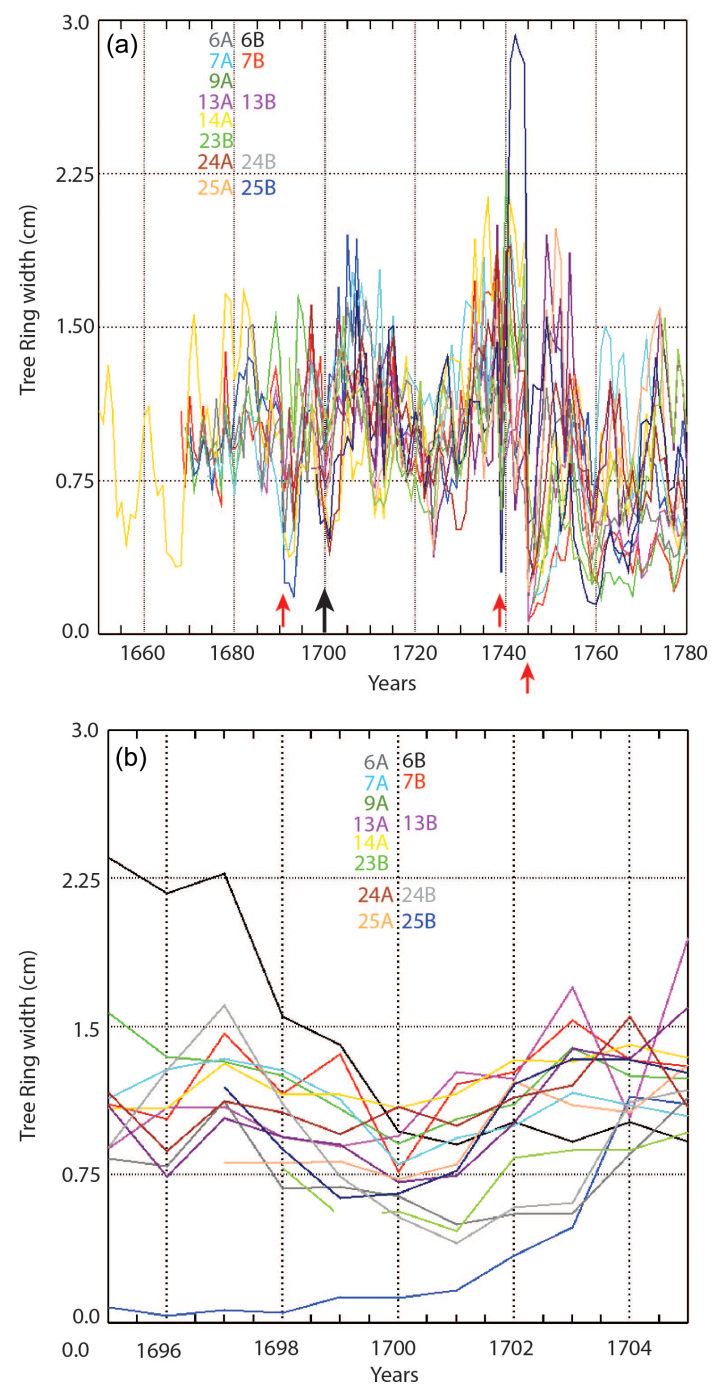

Figure 4. (a) Tree-ring growth records of old-growth Douglas-fir trees (Pseudotsuga menziesii) located in Mike Miller State Park, South Beach, Oregon (see Fig. 1). The vertical axis shows ring growth (in $\mathrm{cm}$ ), and the time range covers several decades before and after $1700 \mathrm{CE}$. The color of each growth record relates to alphanumeric labels of individual trees shown in the legend, with the location of trees shown in Fig. 3b. The designation "A/B" represents two cores from the same tree. The black arrow marks the $1700 \mathrm{CE}$ date, and red arrows highlight the 1691, 1738, and 1745 CE large growth reductions that may have been caused by significant climatological events. Panel (b) shows detailed growth record of trees in (a) 4 years before and after 1700 .

in this area may have experienced as much as $\sim 10 \mathrm{~m}$ of inundation depth, several trees are also on high ground and may have experienced much less, or even zero, inundation.

Tree-ring data detrended using negative exponential functions did not reveal major stand-wide releases or suppressions around 1700 (data not shown) nor did data detrended using the 50-year spline functions. Detailed examination of the growth-ring samples indicates that although individual 
cores have below-average growth, and one experiences what could be interpreted as a post-1700 growth release, variability around 1700 is not necessarily exceptional in the longerterm context of the $\sim 310$-year history of the dataset (Fig. 4a and b). Indeed, there are several other growth reductions in the record that are the same magnitude or larger than the disturbance at $1700 \mathrm{CE}$. Most notably, there are large suppressions observed beginning around 1691 and again in 1739 and 1745 (arrows on Fig. 4a). The 1739 reduction has been observed in other old-growth stand chronologies throughout Cascadia and may be due to a significant climatological event such as a drought (Carroll and Jules, 2005; Carroll et al., 2014).

\subsection{Control sites in western Oregon Cascades and Coast Range}

To better detect unusual growth anomalies around 1700, we compared the South Beach Douglas-fir tree-ring data to two other Douglas-fir datasets from the Oregon Coast Range and one from the western Cascade Mountains, all of which would have experienced similar climate conditions but not tsunami inundation. The first of these was an old-growth stand on Marys Peak ( $\sim 46 \mathrm{~km}$ east of South Beach) in the central coast range. The second is Browder Creek located $\sim 160 \mathrm{~km}$ east in the western Cascade Mountains (Black et al., 2015; Fig. 5a and $b$ ). The third was a chronology generated from samples of dead trees in lakes in the western and central Oregon Coast Range. These lakes had formed when landslides impounded streams, and the preserved drowned trees were then used to establish the date of lake formation, and thus the landslide event (Struble et al., 2020). Eight lakes had a combined number of 15 trees (and 31 sets of measurements) that pre-dated 1700 and were used to generate a "control" chronology. As with Mike Miller trees, all measurement time series in the control datasets were detrended with 50-year splines. The Oregon Coast Range sites range in elevation from $137 \mathrm{~m}$ (Hamar Lake) to $380 \mathrm{~m}$ (Klickitat Lake), with the exception of Marys Peak, which is $900 \mathrm{~m}$. The lone western Cascade site, Browder Creek, is $1108 \mathrm{~m}$. All sites are at low enough elevation that they are most limited by summer (July-September) drought as opposed to higher-elevation sites that are most sensitive to temperature. Relationships with drought are somewhat stronger at Marys Peak and Browder Creek, but this is likely due to their more inland locations.

When compared to the control sites, South Beach tree growth is significantly lower than the lakes, Marys Peak, or Browder Creek in 1700 ( $t$ test of $p<0.001)$ after detrending all series with the 50-year 50\% frequency-cutoff cubic splines. Moreover, the lake trees and Marys Peak trees do not significantly differ in growth in 1700, suggesting the South Beach Douglas-fir growth is unusually low across sites with the most similar climatic histories and sensitivities.

\section{Discussion}

Analysis of tree-ring data presented here indicates there is a reduction in Douglas-fir tree growth at a site associated with the 1700 Cascadia Subduction Zone earthquake and tsunami in South Beach, Oregon, relative to other inland sites in the Oregon Coast Range. The growth reduction is not outside the range of variability, as illustrated by other much more severe reductions over the 310-year South Beach chronology (Fig. 5a and b). However, there is at least a subtle growth reduction that deviates from other nearby locations. Although beyond the scope of this study, further chemical analysis is needed to show that the tree rings collected at South Beach exhibit higher $\delta^{13} \mathrm{C}$ or water-soluble ion levels to establish that the trees here were immersed in seawater.

The tsunami inundation model presented here, which assumes the L- or large-sized earthquake $\left(M_{\mathrm{w}}=9.0\right)$ for the 1700 event (Wei, 2017), shows the resulting tsunami would have inundated the South Beach Douglas-fir stand. The growth reduction in Douglas-fir at South Beach is less pronounced than those observed following the 2011 Japanese tsunami or the post-1700 growth suppressions observed by Jacoby et al. (1997) along the Columbia River $\sim 220 \mathrm{~km}$ to the north of our study site. While modest, spanning no more than 2 years relative to the control sites, and not absolute conclusive evidence, the growth reduction is at least consistent with such an event and with both the magnitude and multiyear time period of growth reductions observed by Jacoby et al. (1997) along the Columbia River $\sim 220 \mathrm{~km}$ to the north.

Speculatively, the observed growth reductions could possibly represent multiple large earthquakes (magnitude $8+$ ) over that time period rather than one great magnitude 9 earthquake at 1700 . Although we cannot rule out multiple earthquakes using our tree-ring growth data, the record of the orphan tsunami in Japan is evidence that only one large earthquake occurred. Moreover, the tsunami inundation model presented here would not necessarily need to change in the multiple earthquake scenario since zero inundation at the old growth stand in South Beach is one possible model result.

Although tree rings and various geologic lines of evidence have been useful in establishing the date of the last Cascadia earthquake, there is still some question as to the degree of peak ground motion associated with the event. As previously discussed, a coastal-wide inventory of liquefaction features associated with the $1700 \mathrm{CSZ}$ event indicate only moderate levels of ground shaking in coastal Oregon and Washington (Obermeier and Dickenson, 2000). Multiple, smaller magnitude megathrust earthquakes before, during, and after 1700 would be one possible explanation for a lower than expected peak ground motion and fewer observed liquefaction features throughout the region. Mapping seismically induced landslides in the Oregon Coast Range is potentially another means to assess levels and distribution of seismic shaking impacts from the $1700 \mathrm{CSZ}$ event, given large-magnitude earthquakes in mountainous regions around 

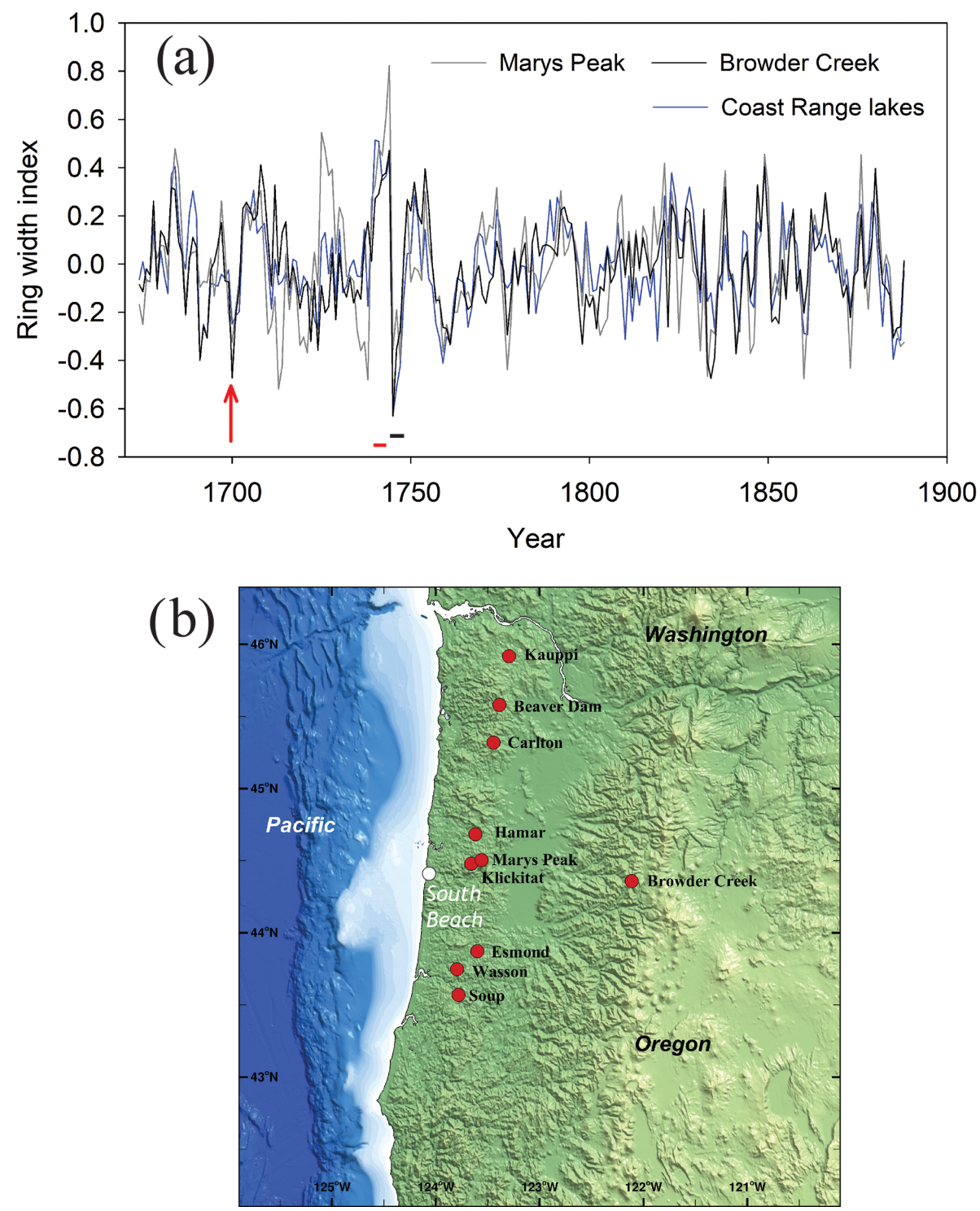

Figure 5. (a) Difference in growth chronologies between Mike Miller and reference sites at Marys Peak, Browder Creek, and Oregon Coast Range lake sites. The $1700 \mathrm{CE}$ chronology indicated by the red arrow, and the significant growth differences between coast and inland sites in 1739-1741 and 1745-1748 are highlighted by red and black lines, respectively. Panel (b) shows location map with Marys Peak and lake sites relative to South Beach. The number of cores available at each site during the 1700 time period are South Beach (14), Marys Peak (28), Oregon Coast Range lakes (31), and Browder Creek (30). The Oregon Coast Range lakes include Beaver Dam Lake, Carlton Lake, Esmond Lake, Hamar Lake, Kauppi Lake, Klickitat Lake, Soup Lake, and Wasson Lake. Map created using digital elevation data points complied by the National Center for Environmental Information (http://ncei.noaa.gov, last access: September 2020).

the world typically trigger thousands of landslides, and slope failures constitute a significant proportion of the damage associated with these events (Stuble et al., 2020). Recent studies have demonstrated the utility of dendrochronology to date the ages of landslides in these settings (Stuble et al., 2020). However, despite the Oregon Coast Range exhibiting thousands of landslides, none have been conclusively associated with the 1700 subduction earthquake, and despite proximity to the megathrust rupture, most deep-seated landslides in the Oregon Coast Range were triggered by rainfall (Perkins et al., 2018; LaHusen et al., 2020; Struble et al., 2020). Thus a continued search for physical evidence of tsunami inundation, earthquake shaking, and coseismic landslides is needed to refine expectations of the inundation, as well as intensity and distribution of ground shaking during future Cascadia megathrust earthquakes. 


\section{Conclusion}

We presented a series of tree-ring data from an old-growth Douglas-fir forest in South Beach, Oregon, that show significant growth reduction at the time of the $1700 \mathrm{CE}$ Cascadia Subduction Zone earthquake relative to control sites. In addition, we presented a new, high-resolution model of the 1700 tsunami inundation at the South Beach old-growth site. Due to significant variation in the South Beach topography, several areas are predicted to experience water levels up to $17 \mathrm{~m}$ and a range of inundation depths up to $16 \mathrm{~m}$; however, the location of the old-growth stand may be subjected to a range of inundation depths from 0 to $10 \mathrm{~m}$. To better detect tree growth anomalies near $1700 \mathrm{CE}$, we also compared the South Beach Douglas-fir tree-ring data to two other Douglasfir datasets from the Oregon Coast Range and western Cascade Mountains which would have experienced similar climate conditions but not tsunami inundation. When compared to these control sites, South Beach tree growth is significantly lower in $1700 \mathrm{CE}$, which reaffirms that the South Beach Douglas-fir growth is unusually low for the region. Thus the timing of the observed growth reductions in the South Beach Douglas-fir stand is consistent with these disturbances being associated with the $1700 \mathrm{CE}$ Cascadia megathrust earthquake and the resulting tsunami, subsidence, and ground motion. Overall, we think our study further supports the view that tree-ring data are a promising tool for providing insights on the spatial distribution of coseismic impacts from megathrust earthquakes, as well as potential ground-truth information for tsunami inundation models.

Code availability. The MOST model was created by Vasily Titov (Titov and Synolakis, 1995, 1998). The MOST codes used in the present study have been re-written utilizing the graphics processing unit (GPU) technology to boost the computational speed. The Boussinesq model codes were created by Hongqiang Zhou (Zhou and Teng, 2010), previously a research scientist at the University of Washington and now a data scientist at TISTA Science and Technology Corporation.

Sample availability. The Mike Miller, Cape Perpetua, and Marys Peak tree-ring data were added to the NOAA National Centers for Environmental Information International Tree-Ring Databank, https://www.ncdc.noaa.gov/data-access/paleoclimatology-data/ datasets/tree-ring (last access: January 2021) (NOAA, 2021).

Author contributions. RPD prepared the manuscript with contributions from all co-authors. BAB and RPD collected the tree-ring samples, performed growth disturbance analysis, and wrote the manuscript. YW developed the tsunami model code, performed the simulations, and wrote the tsunami section of the manuscript. SGM drafted initial maps used in the manuscript.
Competing interests. The authors declare that they have no conflict of interest.

Disclaimer. Publisher's note: Copernicus Publications remains neutral with regard to jurisdictional claims in published maps and institutional affiliations.

Acknowledgements. The authors wish to thank the editor and three reviewers. We also thank Joseph Haxel, Mathew Fowler, and Nuno Simao for helping collect tree cores. The research in this paper was sponsored by the NOAA/Pacific Marine Environmental Laboratory, PMEL paper contribution number 5184. Yong Wei's work is funded by the Joint Institute for the Study of the Atmosphere and Ocean (JISAO) under NOAA Cooperative Agreement NA15OAR4320063, contribution no. 2020-1084. All data are available from the authors upon request, without undue reservation, to any qualified researcher.

Financial support. This project was supported by the National Oceanic and Atmospheric Administration's Pacific Marine Environmental Laboratory.

Review statement. This paper was edited by Maria Ana Baptista and reviewed by Jean Roger and two anonymous referees.

\section{References}

Atwater, B., Satoko, M. R., Satake, K., Yoshinobu, T., Kazue, U., and Yamaguchi, D. K.: The orphan tsunami of 1700-Japanese clues t a parent earthquake in the North America, US Geol. Survey Professional Paper 1707, US Geological Survey, Reston, Virginia, USA, p. 14, 2006.

Atwater, B. F.: Geologic evidence for earthquakes during the past 2000 years along the Copalis River, southern coastal Washington, J. Geophys. Res., 97, 1901-1919, 1992.

Atwater, B. F. and Yamaguchi, D. K.: Sudden, probably coseismic submergence of Holocene trees and grass in coastal Washington State, Geology, 19, 706-709, 1991.

Atwater, B. F., Tuttle, M. P., Schweig, E. S., Rubin, E. S., Yamaguchi, D. K., and Hemphill-Haley, E.: Earthquake recurrence inferred from paleoseismology, Dev. Quatern. Sci., 1, 331-350, 2003.

Black, B. A., Dunham, J. B., Blundon, B. W., Brim-Box, J., and Tepley, A. J.: Long-term growth-increment chronologies reveal diverse influences of climate forcing on freshwater and forest biota in the Pacific Northwest, Global Change Biol., 21, 594 604, 2015.

Buchwal, A., Szczucinski, W., Strzelecki, M., and Long, A. J.: New insights into the 21 November 2000 tsunami in West Greenland from analyses of the tree-ring structure of Salix glauca, Polish Polar Res., 36, 51-65, 2015.

Carroll, A. L. and Jules, E. S.: Climatic assessment of a 580year Chamaecyparis Lawsoniana (Port Orford cedar) tree-ring 
chronology in the Siskiyou mountains, USA, Madrono, 52, 114122,2005

Carroll, A. L., Sillett, S. C., and Kramer, R. D.: MillenniumScale Crossdating and Inter-Annual Climate Sensitivities of Standing California Redwoods, PLOS One, 9, e102545, https://doi.org/10.1371/journal.pone.0102545, 2014.

Chow, V. T.: Open-Channel Hydraulics, McGraw-Hill Book Company, New York, p. 113, 1959.

Cook, E. R. and Krusic, P. J.: ARSTAN v. 41d: A tree-ring standardization program based on detrending and autoregressive time series modeling, with interactive graphics, Tree-Ring Laboratory, Lamont-Doherty Earth Observatory of Columbia University, Palisades, New York, USA, 2005.

Fu, T., Liang, E., Lu, X., Gao, S., Zhang, L., Zhu, H., Rossi, S., and Camarero, J.: Tree growth responses and resilience after the 1950-Zayu-Medog earthquake, southeast Tibetan Plateau, Dendrochronologia, 62, I25724, https://doi.org/10.1016/j.dendro.2020.125724, 2020.

Fuller, M. L.: The New Madrid earthquake, US Geological Survey Bulletin 494, US Geological Survey, Reston, Virginia, USA, 119 pp., 1912.

Goldfinger, C.: Submarine paleoseismology based on turbidite records, Annu. Rev. Mar. Sci., 3, 35-66, 2011.

Goldfinger, C., Nelson, C. H., and Johnson, J. E.: Holocene earthquake records from the Cascadia Subduction Zone and northern San Andreas Fault based on precise dating of offshore turbidites, Annu. Rev. Earth Planet. Sci., 31, 555-577, https://doi.org/10.1146/annurev.earth.31.100901.141246, 2003.

Holmes, R. L.: Computer-assisted quality control in tree-ring dating and measurement, Tree-Ring Bull., 43, 69-78, 1983.

Jacoby, G. C. and Ulan, L. D.: Tree ring indications of uplift at Icy Cape, Alaska, related to 1899 earthquakes, J. Geophys. Res., 88, 9305-9313, https://doi.org/10.1029/JB088iB11p09305, 1983.

Jacoby, G. C., Shepphard, P. R., and Sieh, K. E.: Irregular recurrence of large earthquakes along the San Andreas Fault: Evidence from Trees, Science, 241, 196-199, 1988.

Jacoby, G. C., Bunker, D. E., and Benson, B. E.: Tree-ring evidence for an A.D. 1700 Cascadia earthquake in Washington and northern Oregon, Geology, 25, 999-1002, 1997.

Kathiresan, K. and Rajendran, N.: Coastal mangrove forest mitigated tsunami, Estuar. Coast. Shelf Sci., 65, 601-606, 2005.

Kubota, T., Kagawa, A., and Kodama, N.: Effects of salt water immersion caused by a tsunami on ${ }^{13} \mathrm{C}$ and ${ }^{18} \mathrm{O}$ values of Pinus thunbergii tree-ring cellulose, Ecol. Res., 32, 271-277, 2017.

LaHusen, S. R., Duvall, A. R., Booth, A. M., Grant, A., Mishkin, B. A., Montgomery, D. R., Struble, W., Roering, J. J., and Wartman, J.: Rainfall triggers more deep-seated landslides than Cascadia earthquakes in the Oregon Coast Range, USA, Sci. Adv., 6, eaba6790, https://doi.org/10.1126/sciadv.aba6790, 2020.

Lopez Caceres, M. L., Kakano, S., Ferrio, J. P., Hayashi, M., Nakatsuka, T., Yamanaka, T., and Nobori, Y.: Evaluation of the effect of the 2011 tsunami on coastal forests by means of multiple isotopic analyses of tree-rings, Isotop. Environ. Health Stud., 54, 494-507, https://doi.org/10.1080/10256016.2018.1495203, 2018.

Meisling, K. E. and Sieh, K. E.: Disturbance of trees by the 1857 Fort Tejon earthquake, CA, J. Geophys. Res., 85, 32253238,1980 .
Nelson, A. R., Atwater, B. F., Bobrowsky, P. T., Bradley, L. A., Clague, J. J., Carver, G. A., Darienzo, M. K., Grant, W. C., Kruger, H. W., Sparks, R., Stafford, T. W., and Stuiver, M.: Radiocarbon evidence for extensive plate-boundary rupture about 300 years ago at the Cascadia subduction zone, Nature, 378, 371374, 1995 .

NOAA: Tree Ring, available at: https://www.ncdc.noaa.gov/ data-access/paleoclimatology-data/datasets/tree-ring, last access: January 2021.

Obermeier, S. F. and Dickenson, S. E.: Liquefaction evidence for the strength of ground motion resulting from Late Holocene Cascadia Subduction earthquakes, with emphasis on the event of 1700 AD, Bull. Seismol. Soc. Am., 90, 876-896, 2000.

Perkins, J. P., Roering, J. J., Burns, W. J., Struble, W., Black, B. A., Schmidt, K. M., Duvall, A., and Calhoun, N.: Hunting for landslides from Cascadia's great earthquakes, Eos Am. Geophys. Un., 9 pp., 8 August 2018.

Phipps, R. L.: Collecting, preparing, crossdating, and measuring increment cores, US Geological Survey Water-Resources Investigations Report 85-4148, US Geological Surve, Reston, Virginia, USA, 1-47, 1985.

Priest, G. R., Witter, R. C., Zhang, Y. J., and Wang, K.: Tsunami inundation scenarios for Oregon, Open-file Report 0-13-19, State of Oregon Department of Geology and Mineral Industries, Portland, Oregon, USA, 14 pp., 2013.

Satake, K., Shimazaki, K., Shuji, Y., and Ueda, K.: Time and size of a giant earthquake in Cascadia inferred from Japanese tsunami records of January 1700, Nature, 379, 246-249, 1996.

Satake, K., Wang, K., and Atwater, B. F.: Fault slip and seismic moment of the 1700 Cascadia earthquake inferred from Japanese tsunami descriptions, J. Geophys. Res., 108, 2535, https://doi.org/10.1029/2003JB002521, 2003.

Sheppard, P. R. and Jacoby, G. C.: Application of tree-ring analysis to paleoseismology: Two case studies, Geology, 17, 226-229, 1989.

Struble, W. T., Roering, J. J., Black, B. A., Burns, W. J., Calhoun, N., and Wetherell, L.: Dendrochronological dating of landslides in western Oregon: Searching for signals of the Cascadia A.D. 1700 earthquake, Geol. Soc. Am. Bull., 132, 1775-1791, https://doi.org/10.1130/B35269.1, 2020.

Tang, L., Titov, V. V., and Chamberlin, C. D.: Development, testing, and applications of site-specific tsunami inundation models for real-time forecasting, J. Geophys. Res., 114, C12025, https://doi.org/10.1029/2009JC005476, 2009.

Titov, V. V. and Gonzalez, F. I.: Implementation and testing of the method of splitting tsunami (MOST) model, NOAA Technical Memorandum ERL PMEL-112, NOAA, Silver Spring, MD, USA, 11 pp., 1997.

Titov, V. V. and Synolakis, C. E.: Modeling of breaking and nonbrealing long-wave evolution and runup using VTCS-2, J. Waterw. Port Coast. Ocean Eng., 121, 308-316, 1995.

Titov, V. V. and Synolakis, C. E.: Numerical modeling of tidal wave runup, J. Waterw. Port Coast. Ocean Eng., 124, 157-171, 1998.

Titov, V. V., Kânoğlu, U., and Synolakis, C.: Development of MOST for real-time tsunami forecasting, J. Waterw. Port Coast. Ocean Eng., 142, 03116004, https://doi.org/10.1061/(ASCE)WW.19435460.0000357, 2016.

Udo, K., Sugawara, D., Tanaka, H., Imai, K., and Mano, A.: Impact of the 2011 Tohoku earthquake and tsunami on beach morphol- 
ogy along the northern Sendai coast, Coast. Eng. J., 54, 1250009, https://doi.org/10.1142/s057856341250009x, 2012.

Van Arsdale, R. B., Stahle, D. W., Cleaveland, M. K., and Guccione, M. J.: Earthquake signals in tree-ring data from the New Madrid seismic zone and implications for paleoseismicity, Geology, 26, 515-518, https://doi.org/10.1130/00917613(1998)026<0515:ESITRD>2.3.CO;2, 1998.

Wallace, R. E. and LaMarche, V. C.: Trees as indicators of past movements on the San Andreas Fault, Earthq. Inform. Bull., 2, 127-131, 1979.

Wang, W., McDonald, N. G., Ward, N. D., Indivero, J., Gunn, C., and Bailey, V. L.: Constrained tree growth and gas exchange of seawater exposed forests in the Pacific Northwest, U.S.A., J. Ecol., 107, 2541-2552, https://doi.org/10.1111/13652745.13225, 2019.

WDNR: Modeling a magnitude 9.0 earthquake on the Cascadia Subduction Zone off the Pacific Coast, available at: http://www. dnr.wa.gov/Publications/ger_seismic_scenario_cascadia.pdf (last access: September 2020), 2012.

Wei, Y.: Tsunami inundation modeling for the OSU Marine Studies Initiative Building, report, YGH Architecture, Oregon State University, Corvallis, Oregon, USA, p. 39, November 2017.

Wei, Y., Bernard, E., Tang, L., Weiss, R., Titov, V. V., Moore, C., Spillane, M., Hopkins, M., and Kânoğlu, U.: Realtime experimental forecast of the Peruvian tsunami of $\mathrm{Au}-$ gust 2007 for U.S. coastlines, Geophys. Res. Lett., 35, L04609, https://doi.org/10.1029/2007GL032250, 2008.
Wei, Y., Chamberlin, C., Titov, V. V., Tang, L., and Bernard, E. N.: Modeling of the 2011 Japan tsunami - Lessons for near-field forecast, Pure Appl. Geophys., 170, 1309-1331, https://doi.org/10.1007/s00024-012-0519-z, 2013.

Wells, A. and Yetton, M.: Earthquake and tree-ring impacts in the middle and upper Buller River catchment, Earthquake Commission Research Report No. 03/492, Earthquake Commission, Christchurch, New Zealand, 65 pp., 2004.

Witter, R. C., Zhang, Y., Wang, K., Priest, G. R., Goldfinger, C., Stimely, L. L., English, J. T., and Ferro, P. A.: Simulating tsunami inundation at Bandon, Coos County, Oregon, using hypothetical Cascadia and Alaska earthquake scenarios, Special Paper 43, State of Oregon Department of Geology and Mineral Industries, Portland, Oregon, USA, 57 pp., 2011.

Yamaguchi, D. K., Atwater, B. F., Bunker, D. E., Benson, B. E., and Reid, M. S.: Tree-ring dating the 1700 Cascadia earthquake, Nature, 389, 922-923, https://doi.org/10.1038/40048, 1997.

Yeats, R. S.: Living with earthquakes in the Pacific Northwest, a survivor's guide, second edition: Corvallis, Oregon State University Press, Corvallis, Oregon, USA, p. 400, 2004.

Zhou, H. and Teng, M. H.: Extended fourth-order depth-integrated model for water waves and currents generated by submarine landslides, J. Eng. Mech., 136, 506-516, 2010.

Zhou, H., Moore, C. W., Wei, Y., and Titov, V. V.: A nestedgrid Boussinesq-type approach to modelling dispersive propagation and runup of landslide-generated tsunamis, Nat. Hazards Earth Syst. Sci., 11, 2677-2697, https://doi.org/10.5194/nhess11-2677-2011, 2011. 